\title{
Lipid peroxides as endogenous oxidants forming 8-oxo-guanosine and lipid-soluble antioxidants as suppressing agents
}

\author{
Kazuki Kanazawa, ${ }^{1, *}$ Miku Sakamoto, ${ }^{2}$ Ko Kanazawa, ${ }^{1}$ Yoriko Ishigaki, ${ }^{2}$ Yoshiko Aihara, ${ }^{2}$ Takashi Hashimoto ${ }^{2}$ \\ and Masashi Mizuno ${ }^{2}$ \\ ${ }^{1}$ School of Agricultural Regional Vitalization, Kibi International University, Sareo 370-1, Sichi, Minami Awaji 656-0484, Japan \\ ${ }^{2}$ Laboratory of Food and Nutritional Chemistry, Graduate School of Agricultural Science, Kobe University, Rokkodai, Nada-ku, Kobe 657-8501, Japan
}

(Received 21 September, 2015; Accepted 17 November, 2015; Published online 10 June, 2016)

The oxidation of guanosine to 8-oxo-2'-deoxyguanosine (8-oxo-dG) in DNA is closely associated with induction of various diseases, but the endogenous oxidant species involved remains unclear. Hydrogen peroxides $\left(\mathrm{H}_{2} \mathrm{O}_{2}\right)$ have been considered to be the oxidant, while lipid peroxides are another possible oxidant because generated easily in bio-membranes surrounding DNA. The oxidant potency was compared between lipid peroxides and $\mathrm{H}_{2} \mathrm{O}_{2}$. Linoleic acid hydroperoxides (LOOH) formed 8-oxo-dG at a higher level than $\mathrm{H}_{2} \mathrm{O}_{2}$ in guanosine or double-stranded DNA. In the presence of a physiological concentration of $\mathrm{Fe}^{2+}$ to produce hydroxyl radicals, $\mathrm{LOOH}$ was also a stronger oxidant. In a lipid micelle, LOOH markedly produced 8-oxo-dG at a concentration one-tenth of that of $\mathrm{H}_{2} \mathrm{O}_{2}$. Upon adding to rat hepatic mitochondria, phosphatidylcholine hydroperoxides produced 8-oxo-dG abundantly. Employing HepG2 cells after pretreated with glutathione peroxidase inhibitor, $\mathrm{LOOH}$ formed 8-oxo-dG more abundantly than $\mathrm{H}_{2} \mathrm{O}_{2}$. Then, antioxidants to suppress the 8-oxo-dG formation were examined, when the nuclei of pre-incubated HepG2 with antioxidants were exposed to LOOH. Water-soluble ascorbic acid, trolox, and $\mathrm{N}$ acetyl cysteine showed no or weak antioxidant potency, while lipid-soluble 2,6-dipalmitoyl ascorbic acid, $\alpha$-tocopherol, and lipidsoluble phytochemicals exhibited stronger potency. The present study shows preferential formation of 8-oxo-dG upon LOOH and the inhibition by lipid-soluble antioxidants.

Key Words: 8-OHdG, lipid peroxides, hydrogen peroxide, oxidation of guanosine, lipid-soluble antioxidants

$\mathrm{T}$ he oxidative injury of DNA is closely associated with the induction of degenerative diseases including cancer. Among DNA bases, deoxyguanosine $(\mathrm{dG})$ is most easily oxidized and forms 8-oxo-2'-deoxyguanosine (8-oxo-dG) because its 8-position is substitutable and has very low redox potential. ${ }^{(1)}$ The formed 8oxo-dG can pair with adenine and lead to $\mathrm{G}: \mathrm{C} \rightarrow \mathrm{T}: \mathrm{A}$ transversion mutations unless repaired before replication. ${ }^{(2,3)}$ Indeed, 8-oxo-dG has been frequently detected in mutated genes, carcinomas, and tumors cells, ${ }^{(4-8)}$ and the 8 -oxo-dG levels have been adopted as a biomarker of oxidative stress, which causes degenerative diseases. $^{(1,9-11)}$ Thus, the formation of 8-oxo-dG in DNA has been considered to cause the induction of severe diseases. However, some issues regarding the mechanism of formation of 8-oxo-dG remain unclear and particularly the endogenous oxidants that generate 8 -oxo-dG are unclear. ${ }^{(12,13)}$ Knowledge of such endogenous oxidants will promote our understanding of antioxidants that can prevent disease.

Endogenous oxidants are superoxide anion and its derivatives, such as $\mathrm{H}_{2} \mathrm{O}_{2}$, lipid peroxides, $\mathrm{OH}$ radical, and peroxynitrite. ${ }^{(14-16)}$ Another reactive oxygen species, singlet oxygen, is electronically excited molecular oxygen that is produced by photochemical reactions or biological dark reactions with chloroperoxidase, lactoperoxidase, and lipoxygenase, and is also generated in humans but is not frequently. ${ }^{(17,18)}$ It has been generally recognized that superoxide anion does not attack dG directly and that it can attack guanosine after being dis-proportionated to $\mathrm{H}_{2} \mathrm{O}_{2}$ and decomposed to $\mathrm{OH}$ radical. ${ }^{(19)}$ Peroxynitrite cannot so frequently participate in the formation of 8-oxo-dG. ${ }^{(20,21)}$ Thus, candidates for the endogenous oxidants that form 8-oxo-dG would be $\mathrm{H}_{2} \mathrm{O}_{2}$, lipid peroxides, and/or $\mathrm{OH}$ radical, generating it from peroxides, and the formation of 8-oxo-dG by $\mathrm{OH}$ radical has been considered as shown in Fig. 1. ${ }^{(22)}$

$\mathrm{OH}$ radical is generated endogenously through Fenton's reaction from $\mathrm{H}_{2} \mathrm{O}_{2}$. Fenton's reaction requires transition metals such as $\mathrm{Cu}^{+}$and $\mathrm{Fe}^{2+}$. 23,24$)$ Additionally, the half-life of the $\mathrm{OH}$ radical generated is very short, approximately $10^{-9} \mathrm{~s}^{(25)}$ These factors indicate that transition metals and $\mathrm{H}_{2} \mathrm{O}_{2}$ should coexist near DNA for 8-oxo-dG production, and such coexistence is highly limited in living cells. In contrast, lipid peroxides are easily generated by various reactive oxygen species and increase in the concentration in membranous phospholipids, and their half-life is markedly longer than that of $\mathrm{OH}$ radical, at $7 \mathrm{~s} .{ }^{(26,27)}$ Additionally, the second position of membranous phospholipids is composed abundantly of polyunsaturated fatty acids. Thus, lipid peroxides can arise in nuclear and mitochondrial membranes. Particularly in the inner mitochondrial membrane, the mitochondrial electron transfer system easily generates superoxide anion and peroxidizes membranous lipid. ${ }^{(14,16)}$ The lipid peroxides generated are assumed to attack mitochondrial DNA readily because of being located close by in the inner membrane. Hruszkewycz et al. ${ }^{(28)}$ showed that isolated mitochondria produced $8-0 x 0-\mathrm{dG}$ by the induction of lipid peroxidation. Park et al. ${ }^{(26)}$ showed that calf thymus DNA produced 8-oxo-dG when mixed with peroxidizing lipids. Additionally, in our previous study, the formation of 8-oxo-dG from $\mathrm{dG}$ required the coexistence of thymidine and the formation of peroxide on the C-5 methyl of thymidine. ${ }^{(13)}$ Thus, the lipid peroxides may be the strongest candidate for an endogenous oxidant to produce 8-oxo-dG.

In the present study, we prepared linoleic acid hydroperoxides ( $\mathrm{LOOH})$ and phosphatidylcholine hydroperoxides (PCOOH) for the lipid peroxides, and compared them in terms of the production potency of 8-oxo-dG with $\mathrm{H}_{2} \mathrm{O}_{2}$. In addition, dietary bioavailable antioxidants were examined in terms of suppressing the formation of 8-oxo-dG.

*To whom correspondence should be addressed. E-mail: kazuki@kiui.ac.jp 

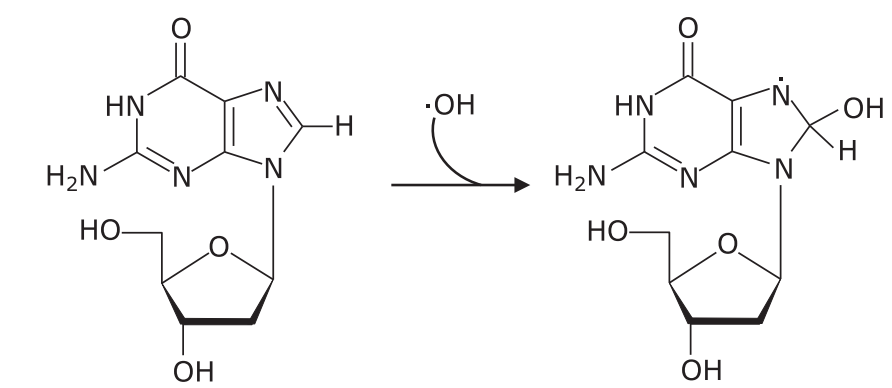

2'-deoxyguanosine (dG)<smiles>Cc1nc2c(=O)[nH]c(N)nc2n1C1CC(O)C2CC1O2</smiles>

8-hydroxy-2'-deoxyguanosine

(8-OHdG) 8-oxo-2'-deoxyguanosine

(8-oxo-dG)

Fig. 1. Formation of 8-oxo-2'-deoxyguanosine (8-oxo-dG) from 2'-deoxyguanosine by $\mathrm{OH}$ radicals. $\mathrm{C} 8-\mathrm{OH}$-adduct radical that formed by an attack of $\mathrm{OH}$ radical to 2 '-deoxyguanosine is followed by oxidation to 8-OHdG or its tautomer 8-oxo-dG.

\section{Materials and Methods}

Chemicals. dG was purchased from Wako Pure Chem. Ind., Ltd. (Osaka, Japan), which contained 8-oxo-dG at a level of $0.60 \pm 0.15$ per $10^{5} \mathrm{dG}$. Standard 8-oxo-dG and calf thymus DNA (type I, highly polymerized) were obtained from Sigma (St. Louis, MO). Ascorbic acid, DL- $\alpha$-tocopherol, and $N$-acetyl-L-cysteine (NAC) were purchased from Nacalai Tesque (Kyoto, Japan). All other reagents used were of the highest grade available from commercial sources.

Preparation of lipid peroxides. $\mathrm{LOOH}$ was prepared from auto-oxidized linoleic acid, as mentioned previously. ${ }^{(29)}$ Briefly, the auto-oxidized linoleic acid was first purified by silica gel column chromatography and then HPLC equipped with a column of SILICA $(5 \mu \mathrm{m}$ mesh and $\varphi 4.6 \times 250 \mathrm{~mm}$, SG120; Shiseido, Tokyo, Japan) eluting with a mixed mobile solvent of $97.3 \%$ $n$-hexane, $2.5 \%$ isopropyl alcohol, and $0.2 \%$ acetic acid $(\mathrm{v} / \mathrm{v})$. The fraction of four LOOH isomers, 13-hydroperoxy- $(9 Z, 11 E)$ and 13-hydroperoxy- $(9 E, 11 E)$-octadeca-9,11-dienoic acid, and 9hydroperoxy-(10E,12Z)- and 9-hydroperoxy-(10E,12E)-octadeca10,12-dienoic acid, were collected, and they were characterized in terms of the peroxide value (PV) and UV absorption at $233 \mathrm{~nm}$ for conjugated diene after drying under a nitrogen gas stream. ${ }^{(30,31)}$ The PV was $3.32 \mu \mathrm{eq} / \mathrm{kg}$ in $0.16 \mathrm{mg}$ of dried LOOH (M.W., 294) and the concentration of conjugated diene was $0.53 \mu \mathrm{mol} / \mathrm{L}$ in $0.16 \mathrm{mg}$; the purity of LOOH was thus calculated to be more than $97 \%$ as linoleic acid hydroperoxides. $\mathrm{LOOH}$ at a concentration of $100 \mathrm{mmol} / \mathrm{L}$ in methanol was stored at $-30^{\circ} \mathrm{C}$ in the dark until use.

Phosphatidylcholine hydroperoxides $(\mathrm{PCOOH})$ were prepared and purified according to the method of Wrona. ${ }^{(32)}$ Briefly, phosphatidylcholine at $20 \mathrm{mg}$ was dissolved in $2 \mathrm{ml}$ of chloroform/ methanol $(1: 1)$ and autoxidized at $37^{\circ} \mathrm{C}$ for 5 days. After being dried and dissolved in $1 \mathrm{ml}$ of methanol, the autoxidized phosphatidylcholine was purified by HPLC under the following conditions: column, Capcell pak $\mathrm{C} 18 \mathrm{MG}$ maintained at $35^{\circ} \mathrm{C}$; mobile phase, a mixed solvent of $95 \%$ methanol and $5 \%$ water; and flow rate, $2.0 \mathrm{ml} / \mathrm{min}$. The collected fraction of $\mathrm{PCOOH}$ was characterized by PV and UV spectrophotometry similarly to LOOH and determined to be more than $96 \%$ pure.

Exposure of dG and calf thymus DNA to oxidants. $\mathrm{dG}$ at $250 \mu \mathrm{mol} / \mathrm{L}$ or calf thymus DNA at $10 \mu \mathrm{g}$ was added to $1 \mathrm{ml}$ of TE buffer (10 mM Tris-HCl containing $1 \mathrm{mM}$ EDTA at $\mathrm{pH} 7.4)$ and $1 \mathrm{mM}$ ethylene diamine tetraacetate (EDTA) and mixed in $50 \mu \mathrm{mol} / \mathrm{L} \mathrm{LOOH}$ or $\mathrm{H}_{2} \mathrm{O}_{2}$, followed by incubation with or without $\mathrm{FeSO}_{4}$ at $37^{\circ} \mathrm{C}$ for $1 \mathrm{~h}$. The $\mathrm{dG}$ mixture was subsequently subjected to determination of the production of 8-oxo-dG by HPLC. In the case of calf thymus mixture, the DNA was precipitated by adding $110 \mu \mathrm{l}$ of $1 \mathrm{M} \mathrm{NaI}$ and $750 \mu \mathrm{l}$ of ice-cold 2propanol and centrifuged at $20,600 \times g$ for $15 \mathrm{~min}$ at $4^{\circ} \mathrm{C}$ after the $1 \mathrm{~h}$ incubation. The precipitate was washed with $70 \%$ ethanol twice and then stored at $-80^{\circ} \mathrm{C}$ until analysis.

\section{Oxidation of $\mathbf{d G}$ in a lipid micelle containing oxidants.}

A lipid micelle was prepared according to a method described previously. ${ }^{(33)}$ Briefly, $19.4 \mathrm{mg}$ of taurocholic acid sodium salt hydrate in $500 \mu \mathrm{l}$ of ethanol was dried under a nitrogen gas stream and added to a mixture of $100 \mu \mathrm{l}$ of potassium phosphate buffer (10 mM, pH 7.4) containing $12.5 \mathrm{mmol} / \mathrm{L}$ lysophosphatidylcholine, $25 \mathrm{mmol} / \mathrm{L}$ mono-olein, and $10 \mu \mathrm{l}$ of methanol solution containing $150 \mathrm{mmol} / \mathrm{L}$ oleic acid or linoleic acid, or a mixture of $145 \mathrm{mmol} / \mathrm{L}$ linoleic acid and $5.0 \mathrm{mmol} / \mathrm{L} \mathrm{LOOH}$. This mixture was added to $50 \mu \mathrm{l}$ of $250 \mu \mathrm{mol} / \mathrm{L} \mathrm{dG}$ in $10 \mathrm{mM}$ potassium phosphate buffer ( $\mathrm{pH}$ 7.4) and with or without $\mathrm{FeSO}_{4}$ and $1.0 \mathrm{mmol} / \mathrm{L} \mathrm{H}_{2} \mathrm{O}_{2}$, and was then vortexed for $1 \mathrm{~min}$ and filled up to $1 \mathrm{ml}$ with $n$-hexane. After incubation at $37^{\circ} \mathrm{C}$ for $1 \mathrm{~h}$, the micelle suspension was extracted with $250 \mu \mathrm{l}$ of TE buffer and a $25 \mu \mathrm{l}$ aliquot of it was analyzed by HPLC to determine 8-oxo-dG.

Treatment of rat hepatic mitochondria with oxidants.

The animal study was approved by the Institutional Animal Care 
and Use Committee (permission number 22-05-27) and carried out according to Kobe University Animal Experimentation Regulations. Male Wistar-ST rats, 11 weeks old, 320-340 g in body weight, were obtained from Japan SLC (Shizuoka, Japan) and housed under a $12 \mathrm{~h}$ light/dark cycle at a constant temperature of $22 \pm 2{ }^{\circ} \mathrm{C}$ for 1 week, allowing free access to a rodent diet (PMI Nutrition International, St. Louis, MO) and water. After anesthesia with $5 \%$ pentobarbital, the liver was isolated and perfused with ice-cold $1.15 \% \mathrm{KCl}$, and immediately frozen in liquid nitrogen and stored at $-80^{\circ} \mathrm{C}$ until the following mitochondrial experiments.

The hepatic mitochondria were prepared at $4{ }^{\circ} \mathrm{C}$ according to a previously described method. ${ }^{(34)}$ Around $2 \mathrm{~g}$ of liver was cut into small pieces and homogenized in $12 \mathrm{ml}$ of sucrose buffer containing $0.25 \mathrm{M}$ sucrose, $5 \mathrm{mM} N$-(2-hydroxyethyl)piperazine- $N{ }^{\prime}$ (2-ethanesulfonic acid) (HEPES), and $0.5 \mathrm{mM}$ ethylene glycolbis ( $\beta$-aminoethyl ether) $N, N, N^{\prime}, N^{\prime}$-tetraacetic acid ( $\left.\mathrm{pH} 7.5\right)$ using Multi-Beads shocker (YASUI KIKAI, Osaka, Japan), and then centrifuged at $100 \times g$ for $5 \mathrm{~min}$. The supernatant was centrifuged again at $600 \times g$ for $10 \mathrm{~min}$, and the supernatant was further centrifuged at $5,500 \times g$ for $20 \mathrm{~min}$. The pellet was suspended in $5 \mathrm{ml}$ of sucrose buffer and washed with centrifugation at $6,000 \times g$ for $20 \mathrm{~min}$ twice. Then, the pellet was incubated with $100 \mu \mathrm{mol} / \mathrm{L}$ LOOH or $\mathrm{H}_{2} \mathrm{O}_{2}$ in $1 \mathrm{ml}$ of HEPES buffer containing $10 \mathrm{mM}$ HEPES and $0.15 \mathrm{M} \mathrm{NaCl}\left(\mathrm{pH} \mathrm{7.4)}\right.$ at $37^{\circ} \mathrm{C}$ for $1 \mathrm{~h}$, and then subjected to the following DNA preparation.

The mitochondria were suspended in $200 \mu \mathrm{l}$ of buffer of $50 \mathrm{mM}$ glucose and $25 \mathrm{mM}$ Tris- $\mathrm{HCl}$ containing $10 \mathrm{mM}$ EDTA (pH 8.0) on ice, and mixed in $400 \mu \mathrm{l}$ of $0.2 \mathrm{M} \mathrm{NaOH}$ containing $1 \%$ sodium dodecyl sulfate (SDS), stirring thoroughly. After standing on ice for $5 \mathrm{~min}$, the mitochondria were added to $300 \mu \mathrm{l}$ of $3 \mathrm{M}$ potassium acetate and allowed to stand at $-80^{\circ} \mathrm{C}$ for $2 \mathrm{~min}$. The suspension was centrifuged at $10,000 \times g$ for $10 \mathrm{~min}$, and $750 \mu \mathrm{l}$ of clear supernatant was mixed in $750 \mu \mathrm{l}$ of 2-propanol standing at $-80^{\circ} \mathrm{C}$ for $5 \mathrm{~min}$. The precipitated DNA was collected by centrifugation at $20,600 \times g$ for 15 min and washed with $70 \%$ ethanol twice, and then was stored at $-80^{\circ} \mathrm{C}$ until 8-oxo-dG determination.

Treatment of HepG2 cells with oxidants. The human hepatocarcinoma cell line HepG2 was cultured in Dulbecco's modified Eagle's medium (DMEM; Nissui Pharmaceutical Co., Tokyo, Japan), seeded at a density of $5 \times 10^{5}$ cells $/ \mathrm{ml}$ on a 100 $\mathrm{mm}$ dish, and cultured for 3 days, as described previously. ${ }^{(35)}$ The medium was changed to fresh serum-free medium containing $100 \mu \mathrm{mol} / \mathrm{L} \mathrm{LOOH}$ or $\mathrm{H}_{2} \mathrm{O}_{2}$ for $2 \mathrm{~h}$ at $37^{\circ} \mathrm{C}$, and then the cells were harvested with $0.25 \%$ trypsin and suspended in $800 \mu \mathrm{l}$ of $0.5 \mathrm{M}$ HEPES-KOH buffer ( $\mathrm{pH} 8.0$ ) including $2 \mathrm{M} \mathrm{KCl}$ and $0.5 \mathrm{M} \mathrm{MgCl}_{2}$. The suspension was placed on ice for $10 \mathrm{~min}$ and homogenized gently using a pellet mixer. After centrifugation at $1,300 \times g$ for $5 \mathrm{~min}$ at $4^{\circ} \mathrm{C}$, the pellet was re-suspended in $5 \mathrm{ml}$ of $0.25 \mathrm{M}$ sucrose buffer containing $2 \mathrm{M}$ Tris- $\mathrm{HCl}(\mathrm{pH} 7.9), 0.5 \mathrm{M}$ $\mathrm{MgCl}_{2}$, and $10 \%$ TritonX-100 and centrifuged at $1,300 \times g$ for $5 \mathrm{~min}$ at $4^{\circ} \mathrm{C}$. The precipitated nuclei were subjected to 8 -oxo-dG determinations.

Alternatively, 3-day-cultured cells were pre-incubated with $500 \mu \mathrm{mol} / \mathrm{L}$ mercaptosuccinic acid, an inhibitor of glutathione peroxidase $(\mathrm{GPx}),{ }^{(36)}$ in fresh medium containing $2 \%$ FBS for $24 \mathrm{~h}$, and then were mixed in $\mathrm{LOOH}$ or $\mathrm{H}_{2} \mathrm{O}_{2}$.

In cells pre-treated with or without mercaptosuccinate, GPx activity was determined by a partly modified version of a method described previously. ${ }^{(37)}$ Briefly, HepG2 cells were washed twice with ice-cold PBS and scraped with $100 \mu \mathrm{l}$ of $0.1 \mathrm{M}$ potassium phosphate buffer ( $\mathrm{pH}$ 6.5) containing $1 \mathrm{~mol} / \mathrm{L}$ phenylmethylsulfonyl fluoride. After 5-s sonication with an ultrasonic cell disruptor (Microson, NY) on ice 6 times, the lysate was centrifuged at $12,000 \times g$ for $20 \mathrm{~min}$ at $4^{\circ} \mathrm{C}$. A total of $100 \mu \mathrm{l}$ of the supernatant was mixed with $1 \mathrm{ml}$ of $0.1 \mathrm{M}$ phosphate buffer $(\mathrm{pH} 7.0)$ containing $4 \mathrm{mM}$ EDTA, $1.2 \mathrm{ml}$ of distilled water, $0.2 \mathrm{ml}$ of $10 \mu \mathrm{M}$ sodium azide, $0.2 \mathrm{ml}$ of $10 \mu \mathrm{M}$ glutathione, $0.2 \mathrm{ml}$ of $1.5 \mathrm{mmol} / \mathrm{L} \mathrm{NADPH}$, and $6 \mu \mathrm{l}$ of $250 \mathrm{U} / \mathrm{ml}$ glutathione reductase.
The mixture was incubated at $37^{\circ} \mathrm{C}$ for $1 \mathrm{~min}$, and was added to $0.1 \mathrm{ml}$ of $1.5 \mathrm{mM} t$-butyl hydroperoxide. Then, the oxidation of NADPH was measured at $340 \mathrm{~nm}$, and GPx activity was expressed as nmoles of the oxidized NADPH per minute per mg of protein after determining the protein amounts by the Lowry method.

Evaluation of antioxidant potency in HepG2 cells. Fourday-cultured HepG2 cells were pre-incubated with $10 \mu \mathrm{mol} / \mathrm{L}$ ascorbic acid, $\alpha$-tocopherol, NAC, or flavonoids, or $3 \mu \mathrm{mol} / \mathrm{L}$ carotenoids in fresh serum-free medium for $1 \mathrm{~h}$ at $37^{\circ} \mathrm{C}$, and the nuclei were isolated. After treatment with $100 \mu \mathrm{mol} / \mathrm{L} \mathrm{LOOH}$ in PBS for another $1 \mathrm{~h}$, the nuclei were washed twice with PBS and lysed with $400 \mu \mathrm{l}$ of TE buffer containing $0.5 \%$ SDS. The lysate was treated with a final concentration of $0.5 \mathrm{mg} / \mathrm{ml}$ ribonuclease A (Sigma) for $30 \mathrm{~min}$ at $50^{\circ} \mathrm{C}$, followed by treatment with $0.5 \mathrm{mg} / \mathrm{ml}$ proteinase K (Sigma) for $1 \mathrm{~h}$ at $50^{\circ} \mathrm{C}$. DNA was precipitated with $0.7 \mathrm{M} \mathrm{NaI}$ and 50\% 2-propanol, and centrifuged at 17,000 $\times \mathrm{g}$ for 15 min at $4{ }^{\circ} \mathrm{C}$. The precipitated nuclei were subjected to 8 -oxo-dG determinations.

Determination of 8-oxo-dG. Before subjecting 8-oxo-dG to HPLC, calf thymus DNA, precipitated nuclei of HepG2 cells, and precipitated DNA of mitochondria were treated as follows: they were denatured in $200 \mu \mathrm{l}$ of $1 \mathrm{mM}$ EDTA by heating at $95^{\circ} \mathrm{C}$ for $5 \mathrm{~min}$ and were immediately cooled on ice for $5 \mathrm{~min}$. The DNA was hydrolyzed with 2.5 units of nuclease $\mathrm{P}_{1}$ (Wako) for $30 \mathrm{~min}$ at $37^{\circ} \mathrm{C}$ and the hydrolysis was stopped by mixing in $0.1 \mathrm{M}$ Tris- $\mathrm{HCl}$ (pH 7.4). Then, the DNA was treated with 3 units of alkaline phosphatase (Sigma) for $1 \mathrm{~h}$ at $37^{\circ} \mathrm{C}$ and centrifuged at $17,000 \times g$ for $10 \mathrm{~min}$ at $4^{\circ} \mathrm{C}$. The supernatant was filtered in a Vivaspin 500 microconcentrator (Sartorius Stedim Biotech, Goettingen, Germany) by centrifugation at $15,000 \times g$ for $20 \mathrm{~min}$ at $4^{\circ} \mathrm{C}$. An aliquot of $25 \mu \mathrm{l}$ was subjected to the following HPLC.

8-Oxo-dG was determined as described previously. ${ }^{(38)}$ Briefly, the HPLC conditions were as follows: column, Capcell pak C18 UG120 (5 $\mu \mathrm{m}$ mesh and $\varphi 4.6 \times 250 \mathrm{~mm}$; Shiseido, Tokyo, Japan) maintained at $35^{\circ} \mathrm{C}$; mobile phase, $6.5 \%$ methanol and $93.5 \%$ $20 \mathrm{mM}$ potassium phosphate buffer $(\mathrm{pH} 4.5)$ containing $0.1 \mathrm{mM}$ EDTA; and flow rate, $1.0 \mathrm{ml} / \mathrm{min}$. 8-Oxo-dG was determined with an electrochemical detector (Nanospace SI-2; Shiseido) at $+600 \mathrm{mV}$, and simultaneously $\mathrm{dG}$ was measured by the UV detector (L-7420; Hitachi, Tokyo, Japan). In this analysis, the determination limit was $2.5 \mathrm{pmol}$ for 8 -oxo-dG. The determined 8 -oxo-dG levels are expressed as mean $\pm \mathrm{SD}$ of the number of 8-oxo-dG molecules per $10^{5} \mathrm{dG}$.

Statistical analysis. The data are reported as the mean \pm SD. Statistical analysis was performed using ANOVA and TukeyKramer. Probability values of $<0.05$ were considered to be statistically significant.

\section{Results}

Comparison of the oxidant potency between $\mathrm{H}_{2} \mathrm{O}_{2}$ and lipid peroxides. The oxidant species forming 8-oxo-dG has been considered to be mainly $\mathrm{H}_{2} \mathrm{O}_{2}$, while lipid peroxides may also be included among such oxidant species because bio-membrane enclosing DNA has abundant polyunsaturated fatty acids that can be frequently peroxidized to lipid peroxides. Thus, the oxidant potency was compared between $\mathrm{H}_{2} \mathrm{O}_{2}$ and $\mathrm{LOOH}$.

Table 1 shows that $\mathrm{LOOH}$ oxidized dG to 8-oxo-dG at the level of $3.35 \pm 0.65 / 10^{5} \mathrm{dG}$ and was a significantly stronger oxidant than $\mathrm{H}_{2} \mathrm{O}_{2}\left(1.91 \pm 0.39 / 10^{5} \mathrm{dG}\right)$ at a concentration of $50 \mu \mathrm{mol} / \mathrm{L}$. The addition of $\mathrm{Fe}^{2+}$ for Fenton's reaction at a physiological concentration of $0.5 \mu \mathrm{mol} / \mathrm{L}$ significantly increased the oxidant potency of $\mathrm{LOOH}$ but did not increase that of $\mathrm{H}_{2} \mathrm{O}_{2} \cdot{ }^{(39,40)}$ The physiologically excessive amount of $\mathrm{Fe}^{2+}$ of $10 \mu \mathrm{mol} / \mathrm{L}$ increased the formation by both $\mathrm{LOOH}$ and $\mathrm{H}_{2} \mathrm{O}_{2}$. Similarly, in Table 2 for calf thymus double-stranded DNA, LOOH exhibited significantly stronger potency as an oxidant than $\mathrm{H}_{2} \mathrm{O}_{2}$ in the absence and 
Table 1. Production of 8-oxo-dG from dG by $\mathrm{H}_{2} \mathrm{O}_{2}$ or $\mathrm{LOOH}$ with or without $\mathrm{Fe}^{2+}$

\begin{tabular}{lcccc}
\hline \multirow{2}{*}{ Substrate* $^{*} \mathrm{Fe}^{2+}(\mu \mathrm{mol} / \mathrm{L})$} & \multicolumn{3}{c}{ Oxidant $(50 \mu \mathrm{mol} / \mathrm{L})$} \\
\cline { 3 - 4 } $\mathrm{dG}(250 \mu \mathrm{mol} / \mathrm{L})$ & 0 & Vehicle & $\mathrm{H}_{2} \mathrm{O}_{2}$ & $\mathrm{LOOH}$ \\
& 0.5 & $0.67 \pm 0.30^{\mathrm{a}}$ & $1.91 \pm 0.39^{\mathrm{a}}$ & $3.35 \pm 0.65^{\mathrm{b}}$ \\
& 10 & $1.27 \pm 0.06^{\mathrm{a}}$ & $1.89 \pm 0.20^{\mathrm{a}}$ & $3.59 \pm 0.47^{\mathrm{b}}$ \\
& & $5.04 \pm 0.29^{\mathrm{c}}$ & $11.55 \pm 0.82^{\mathrm{d}}$ & $8.73 \pm 1.86^{\mathrm{e}}$ \\
\hline
\end{tabular}

*dG was incubated with oxidants as shown in Materials and Methods. The commercial dG originally contained 8-oxo-dG at levels of $0.58 \pm 0.08$ number per $10^{5} \mathrm{dG}$, and the present results include the original amounts of 8-oxo-dG. **Values are mean \pm SD $(n=6)$ and different superscript letters indicate statistically significant differences $(p<0.05)$.

Table 2. Production of 8-oxo-dG in calf thymus DNA by $\mathrm{H}_{2} \mathrm{O}_{2}$ or $\mathrm{LOOH}$ with or without $\mathrm{Fe}^{2+}$

\begin{tabular}{|c|c|c|c|c|}
\hline \multirow{2}{*}{ Substrate* } & \multirow{2}{*}{$\mathrm{Fe}^{2+}(\mu \mathrm{mol} / \mathrm{L})$} & \multicolumn{3}{|c|}{ Oxidant $(50 \mu \mathrm{mol} / \mathrm{L})$} \\
\hline & & Vehicle & $\mathrm{H}_{2} \mathrm{O}_{2}$ & $\mathrm{LOOH}$ \\
\hline & & \multicolumn{3}{|c|}{ Produced number of 8-oxo-dG per $10^{5} \mathrm{dG} * *$} \\
\hline \multirow[t]{3}{*}{ Calf thymus DNA $(10 \mu \mathrm{g} / \mathrm{ml})$} & 0 & $0.94 \pm 0.23^{\mathrm{a}}$ & $9.28 \pm 1.79^{b}$ & $27.16 \pm 1.88^{c}$ \\
\hline & 0.5 & $0.67 \pm 0.13^{\mathrm{a}}$ & $11.20 \pm 1.59^{b}$ & $31.29 \pm 1.20^{c}$ \\
\hline & 10 & $1.62 \pm 0.68^{a}$ & $56.64 \pm 6.71^{d}$ & $62.10 \pm 7.01^{\mathrm{e}}$ \\
\hline
\end{tabular}

*Calf thymus DNA was incubated with oxidants as shown in Materials and Methods. The commercial calf thymus DNA originally contained 8-oxo-dG at levels of $0.60 \pm 0.15$ number per $10^{5} \mathrm{dG}$, and the present results include the original amounts of 8-oxo-dG. $* *$ Values are mean \pm SD $(n=6)$ and different superscript letters indicate statistically significant differences $(p<0.05)$.

Table 3. Production of 8-oxo-dG by $\mathrm{H}_{2} \mathrm{O}_{2}$ or $\mathrm{LOOH}$ in lipid micelles containing dG

\begin{tabular}{ccccc}
\hline \multirow{2}{*}{$\mathrm{Fe}^{2+}(\mu \mathrm{mol} / \mathrm{L})^{1}$} & \multicolumn{4}{c}{ Components of micelles $^{2}$} \\
\cline { 2 - 5 } & Oleic acid $(150 \mu \mathrm{mol} / \mathrm{L})$ & Linoleic acid $(150 \mu \mathrm{mol} / \mathrm{L})$ & $\begin{array}{c}\text { Linoleic acid }(145 \mu \mathrm{mol} / \mathrm{L}) \\
\text { and LOOH }(5.0 \mu \mathrm{mol} / \mathrm{L})\end{array}$ & $\mathrm{H}_{2} \mathrm{O}_{2}(50 \mu \mathrm{mol} / \mathrm{L})^{1}$ \\
\hline & & Produced number of 8-oxo-dG per $10^{5} \mathrm{dG}^{3}$ & \\
0.5 & $0.82 \pm 0.15^{\mathrm{a}}$ & $0.47 \pm 0.07^{\mathrm{a}}$ & $6.04 \pm 0.56^{\mathrm{b}}$ & $2.17 \pm 0.36^{\mathrm{a}}$ \\
10 & $0.97 \pm 0.18^{\mathrm{a}}$ & $0.70 \pm 0.04^{\mathrm{a}}$ & $11.34 \pm 0.38^{\mathrm{c}}$ & $6.93 \pm 1.66^{\mathrm{b}}$ \\
\end{tabular}

${ }^{1} \mathrm{FeSO}_{4}$ and $\mathrm{H}_{2} \mathrm{O}_{2}$ were added to the liposomal mixture prepared as shown in Materials and Methods. ${ }^{2}$ Oleic acid, linoleic acid, or a mixture of linoleic acid and $\mathrm{LOOH}$ was mixed in a suspension of lysophosphatidylcholine and mono-olein as shown in Materials and Methods. ${ }^{3}$ Values are mean \pm SD $(n=6)$ and different letters indicate statistically significant differences $(p<0.05)$. The commercial dG originally contained 8-oxo-dG at levels of $0.58 \pm 0.08$ number per $10^{5} \mathrm{dG}$, and the present results include the original amounts of 8-oxo-dG.

Table 4. Production of 8-oxo-dG in mitochondria of rat hepatocytes upon exposure to oxidants

\begin{tabular}{|c|c|c|c|}
\hline \multirow{2}{*}{ Vehicle } & \multicolumn{3}{|c|}{ Oxidant $(100 \mu \mathrm{mol} / \mathrm{L})$} \\
\hline & $\mathrm{H}_{2} \mathrm{O}_{2}$ & $\mathrm{LOOH}$ & $\mathrm{PCOOH}$ \\
\hline & \multicolumn{3}{|c|}{ Produced number of 8-oxo-dG per $10^{5} \mathrm{dG}^{1}$} \\
\hline$u^{2}{ }^{2}$ & $23.96 \pm 8.54$ & $34.43 \pm 10.18$ & $75.55 \pm 71.3$ \\
\hline
\end{tabular}

presence of a physiological concentration of $\mathrm{Fe}^{2+}$, and produced an amount of 8-oxo-dG similar to that of $\mathrm{H}_{2} \mathrm{O}_{2}$ after the addition of a physiologically excessive amount of $\mathrm{Fe}^{2+}$. Thus, $\mathrm{LOOH}$ was a stronger oxidant of $\mathrm{dG}$ and thymus DNA under physiological conditions.

Bio-membranes enclosing DNA such as the nuclear membrane and the mitochondrial membrane frequently contain lipid peroxides. Here, lipid micelles including oxidants were prepared and compared in terms of their oxidant potency, as shown in Table 3. A few 8-oxo-dG molecules were detected in the micelles composed of a non-oxidized mono-unsaturated fatty acid, oleic acid, and a di-unsaturated fatty acid, linoleic acid. The addition of $\mathrm{H}_{2} \mathrm{O}_{2}$ at $50 \mu \mathrm{mol} / \mathrm{L}$ slightly increased the level of 8-oxo-dG. In contrast, the addition of $\mathrm{LOOH}$ at one-tenth of that level $(5 \mu \mathrm{mol} / \mathrm{L})$ significantly enhanced the production of 8-oxo-dG compared with that by $\mathrm{H}_{2} \mathrm{O}_{2}$. The presence of a physiological concentration of $\mathrm{Fe}^{2+}$ facilitated the production in LOOH micelles more than in $\mathrm{H}_{2} \mathrm{O}_{2}$ micelles.

Table 4 shows the 8 -oxo-dG production in mitochondria prepared from rat liver after treatment with $100 \mu \mathrm{mol} / \mathrm{L} \mathrm{H}_{2} \mathrm{O}_{2}, \mathrm{LOOH}$, or PCOOH. Every oxidant produced considerable amounts of 8-oxo-dG compared with the vehicle controls. $\mathrm{LOOH}$ showed the greater production than $\mathrm{H}_{2} \mathrm{O}_{2}$, and $\mathrm{PCOOH}$ produced even more 8-oxo-dG, but significant differences were not found among these three oxidants.

Production of 8-oxo-dG in HepG2 cell. As one of the models of living cells, HepG2 cells were employed and treated with $\mathrm{H}_{2} \mathrm{O}_{2}$ or $\mathrm{LOOH}$ using the oxidants at the physiologically 
Table 5. Production of 8-oxo-dG by $\mathrm{H}_{2} \mathrm{O}_{2}$ or $\mathrm{LOOH}$ in HepG2 cells

\begin{tabular}{|c|c|c|c|}
\hline \multirow{2}{*}{ Pretreatment with } & \multicolumn{3}{|c|}{ Oxidant $(100 \mu \mathrm{mol} / \mathrm{L})$} \\
\hline & Vehicle & $\mathrm{H}_{2} \mathrm{O}_{2}$ & $\mathrm{LOOH}$ \\
\hline & \multicolumn{3}{|c|}{ Produced number of 8-oxo-dG per $10^{5} \mathrm{dG}^{1}$} \\
\hline None & $0.08 \pm 0.04^{\mathrm{a}}$ & $0.38 \pm 0.15^{b}$ & $0.23 \pm 0.12^{a, b, c_{1} d}$ \\
\hline Mercaptosuccinate 2 & $0.11 \pm 0.03^{a, c}$ & $0.34 \pm 0.11^{b, d}$ & $0.61 \pm 0.04^{\mathrm{e}}$ \\
\hline
\end{tabular}

Values are mean \pm SD $(n=6)$ and different letters indicate statistically significant differences $(p<0.05)$ in the same line. ${ }^{2} \mathrm{HepG} 2$ cells were pre-incubated with $500 \mu \mathrm{mol} / \mathrm{L}$ mercaptosuccinate and then were exposed to $\mathrm{H}_{2} \mathrm{O}_{2}$ or $\mathrm{LOOH}$.<smiles>O=C1OC(C(O)CO)C(O)C1O</smiles>

Ascorbic acid

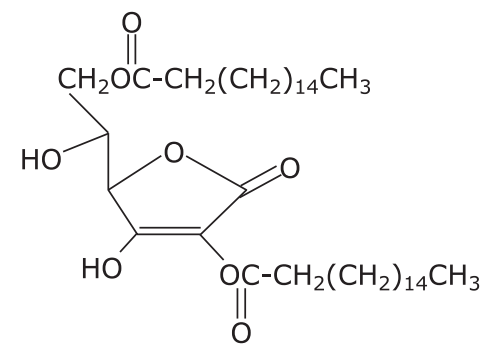

2,6-O-dipaimitoyl ascorbic acid

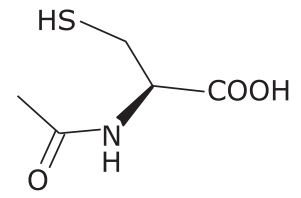

$N$-acetyl-L-cysteine (NAC)<smiles>Cc1c(C)c2c(c(C)c1O)CCC(C)(C(=O)O)O2</smiles><smiles>Cc1c(C)c2c(c(C)c1O)CCC(C)(CCCC(C)CCCC(C)CCCC(C)C)O2</smiles>

Fig. 2. Chemical structures of water- and lipid-soluble antioxidants employing in Fig. 3.

excess concentrations, $100 \mu \mathrm{mol} / \mathrm{L}$, in order to compare in their oxidant potency. Table 5 shows that both oxidants slightly increased 8-oxo-dG levels, and the production by $\mathrm{H}_{2} \mathrm{O}_{2}$ was significant while that by $\mathrm{LOOH}$ was not significant compared to that of vehicle control. Living cells have been shown to possess antioxidant enzymes that can remove peroxides such as GPx. ${ }^{(36)}$ Thus, HepG2 cells were pretreated with an inhibitor of GPx, mercaptosuccinate, before adding the oxidants. $\mathrm{H}_{2} \mathrm{O}_{2}$ and $\mathrm{LOOH}$ significantly elevated the levels of 8-oxo-dG in the cells, and LOOH produced more 8-oxo-dG than $\mathrm{H}_{2} \mathrm{O}_{2}$. Thus, $\mathrm{LOOH}$ was preferential oxidant for the cellular production of 8-oxo-dG under such conditions that GPx was not working.

Suppressing effects of dietary antioxidants on 8-oxo-dG formation. Antioxidants were added to the HepG2 cells for $1 \mathrm{~h}$, and then the nuclei were isolated. After treated with $100 \mu \mathrm{mol} / \mathrm{L}$ $\mathrm{LOOH}$, the nuclei were determined in the formed amounts of 8oxo-dG. First, using chemicals as shown in Fig. 2, the antioxidant potency was compared between water-soluble and lipid-soluble antioxidants. Fig. 3 shows that water-soluble ascorbic acid, torolox and NAC significantly suppressed 8-oxo-dG production to $66 \%, 68 \%$ and $62 \%$, respectively, compared to the production of 8-oxo-dG in a control not treated with antioxidants. In contrast, lipid-soluble 2,6-dipalmitoyl ascorbic acid and $\alpha$-tocopherol inhibited the production more, to $44 \%$ and $37 \%$, respectively, than the water-soluble antioxidants.

Fig. 4 shows the antioxidant potency of flavonoids as shown the chemical structures in Fig. 5 on the 8-oxo-dG formation in nuclei of HepG2 cells exposed to LOOH. Flavone having no $\mathrm{OH}$ groups did not exhibit potency, while a flavonol, 3-OH flavone, significantly suppressed the 8 -oxo-dG formation to $56 \%$ compared to the production in the control. Baicalein, a flavone with 5,6,7-OH groups, and myricetin, a flavonol with 5,7,3',4',5'-OH groups, did

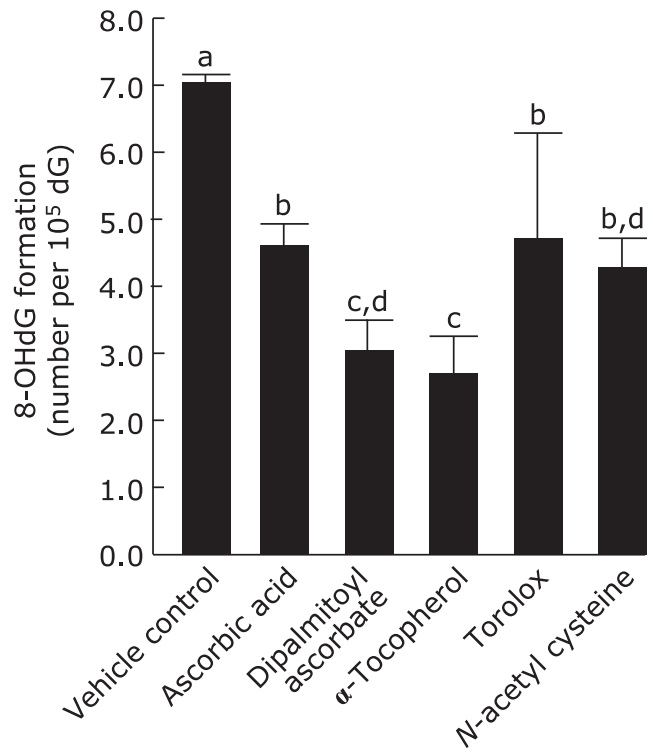

Fig. 3. Suppressing activity of water- and lipid-soluble vitamins on 8-oxo-dG production induced by LOOH in HepG2 cells. HepG2 cells were pre-incubated with $10 \mu \mathrm{mol} / \mathrm{L}$ of the presented chemicals at $37^{\circ} \mathrm{C}$ for $1 \mathrm{~h}$, and then the nuclei were isolated and exposed to $100 \mu \mathrm{mol} / \mathrm{L} \mathrm{LOOH}$ for $1 \mathrm{~h}$. The nuclei were determined in the produced 8-oxo-dG as mentioned in Materials and Methods. Figures are mean \pm SD $(n=6)$ of the number of 8-oxo-dG molecules per $10^{5} \mathrm{dG}$. The most left bar is a control when HepG2 cells were incubated with vehicle $(7.08 \pm 0.07$ per $10^{5} \mathrm{dG}$ ). The different superscript letters indicate statistically significant differences $(p<0.05)$. 


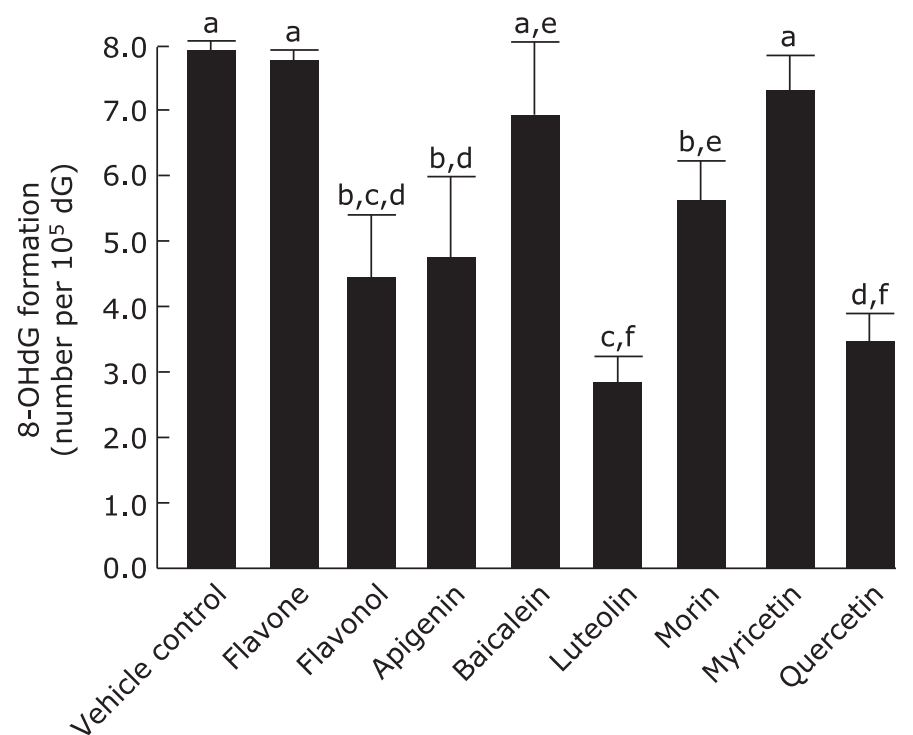

Fig. 4. Suppressing activity of flavonoids on 8-oxo-dG production induced by LOOH in HepG2 cells. After the HepG2 cells had been preincubated with $10 \mu \mathrm{mol} / \mathrm{L}$ of the presented flavonoids at $37^{\circ} \mathrm{C}$ for $1 \mathrm{~h}$, the nuclei were treated as mentioned in Fig. 1. Figures are mean \pm SD $(n=6)$ of the number of 8-oxo-dG molecules per $10^{5} \mathrm{dG}$. The most left bar is a control when HepG2 cells were incubated with vehicle $\left(7.95 \pm 0.14\right.$ per $\left.10^{5} \mathrm{dG}\right)$. The different superscript letters indicate statistically significant differences $(p<0.05)$.

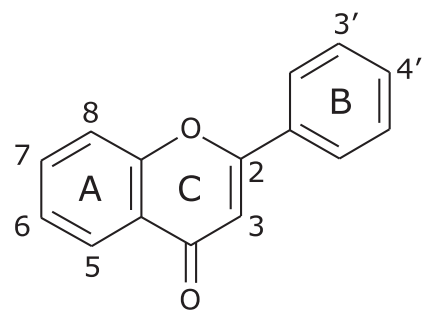

Chemical structure of flavonoid skeleton

\begin{tabular}{ll}
\hline Flavonoid name & Substitution \\
\hline Flavone & no OH \\
Flavonol & $3-\mathrm{OH}$ \\
Apigenin & $5,7,4^{\prime}-\mathrm{OH}$ \\
Baicalein & $5,6,7^{-} \mathrm{OH}$ \\
Luteolin & $5,7,3^{\prime}, 4^{\prime}-\mathrm{OH}$ \\
Morin & $3,5,7^{\prime}, 4^{\prime}-\mathrm{OH}$ \\
Myricetin & $3,5,7^{\prime}, 3^{\prime}, 5^{\prime}-\mathrm{OH}$ \\
Quercetin & $3,5,7^{\prime}, 4^{\prime}-\mathrm{OH}$ \\
\hline
\end{tabular}

Fig. 5. Chemical structures of flavonoids comparing in the antioxidant potency in Fig. 4.

not exhibit the activity. Apigenin, a flavone with 5,7,4'-OH groups, significantly suppressed it to $61 \%$, while morin, a flavonol with $5,7,2^{\prime}, 4^{\prime}-\mathrm{OH}$ groups, did so to $72 \%$, and luteolin, a flavone with $5,7,3^{\prime}, 4^{\prime}-\mathrm{OH}$ groups, and quercetin, a flavonol with $5,7,3^{\prime}, 4^{\prime}-$ $\mathrm{OH}$ groups, exhibited significantly stronger suppression, to $36 \%$ and $44 \%$, respectively.

Fig. 6 shows the antioxidant potencies of carotenoids, showing their chemical structures in Fig. 7. $\beta$-Carotene did not exhibit

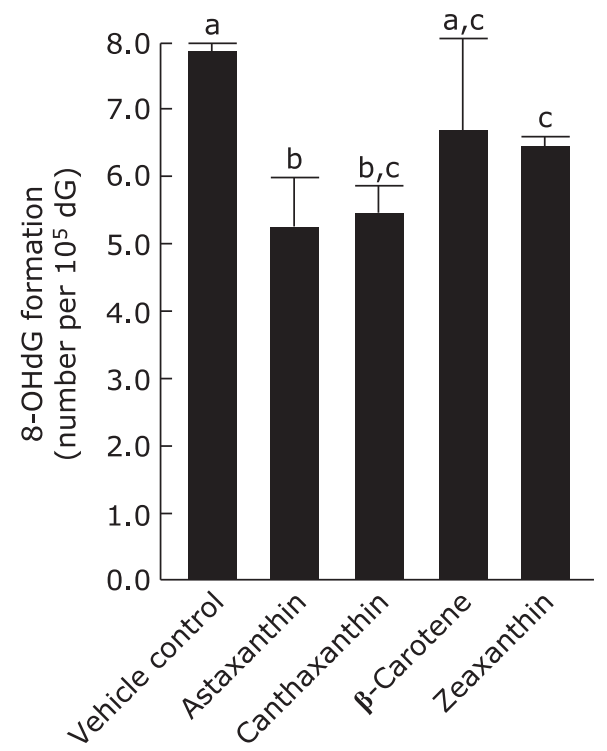

Fig. 6. Suppressing activity of carotenes on 8-oxo-dG production induced by LOOH in HepG2 cells. HepG2 cells were pre-incubated with $3 \mu \mathrm{mol} / \mathrm{L}$ of the presented carotenoids at $37^{\circ} \mathrm{C}$ for $1 \mathrm{~h}$, and the 8 -oxo-dG levels in nuclei were determined as mentioned in Fig. 1. Figures are mean \pm SD $(n=6)$ of the number of 8 -oxo-dG molecules per $10^{5} \mathrm{dG}$. The most left bar is a control when HepG2 cells were incubated with vehicle $\left(7.85 \pm 0.52\right.$ per $\left.10^{5} \mathrm{dG}\right)$. The different superscript letters indicate statistically significant differences $(p<0.05)$.<smiles>CC1=C(/C=C/C(C)=C/C=C(C)/C=C(C)/C=C/C=C/C(C)=C/C=C/C(C)=C/C=C/C(C)=C/C=C(\C)C2=C(C)C(=O)[C@@H](O)CC2(C)C)C(C)(C)C[C@H](O)C1=O</smiles><smiles>CC1=C(/C=C/C(C)=C/C=C/C(C)=C/C=C/C=C(C)/C=C/C=C(C)/C=C/C=C(\C)C2=C(C)CCCC2(C)C)C(C)(C)CCC1</smiles>

$\boldsymbol{\beta}$-Carotene

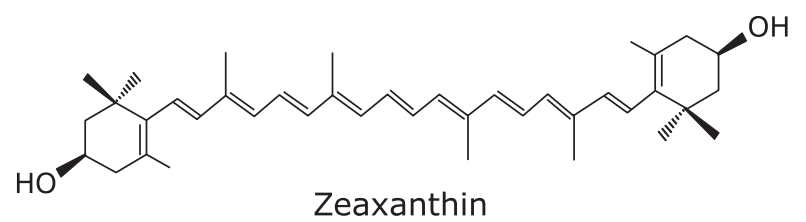

Fig. 7. Chemical structures of carotenoids used in Fig. 6 .

such activity, but xanthophylls, oxygen-containing carotenoids, namely, astaxanthin, canthaxanthin, and zeaxanthin, showed weak but significant antioxidant potency, with suppression to $68 \%$, $70 \%$, and $82 \%$, respectively, compared to the production in the control. 


\section{Discussion}

In living cells, $\mathrm{H}_{2} \mathrm{O}_{2}$ has generally been considered to be the most contributable oxidant species because it easily produces $\mathrm{OH}$ radicals. On the other hand, lipid peroxides such as $\mathrm{LOOH}$ are easily generated in polyunsaturated fatty acids of membranous phospholipids. ${ }^{(14,16,28)}$ The present study compared the oxidant potency between $\mathrm{H}_{2} \mathrm{O}_{2}$ and $\mathrm{LOOH}$, and found that $\mathrm{LOOH}$ markedly oxidizes dG to 8-oxo-dG in DNA, and that lipid-soluble antioxidants could prevent such oxidation.

LOOH is a stronger oxidant for forming 8-oxo-dG than $\mathrm{H}_{2} \mathrm{O}_{2}$ on $\mathrm{dG}$ and double-stranded DNA (Table 1 and 2). Since $\mathrm{H}_{2} \mathrm{O}_{2}$ requires $\mathrm{Cu}^{+}$or $\mathrm{Fe}^{2+}$ to produce the stronger oxidant species of $\mathrm{OH}$ radical, ${ }^{(23,24)} \mathrm{Fe}^{2+}$ was added to the solutions of $\mathrm{dG}$ and DNA. Surprisingly, $\mathrm{H}_{2} \mathrm{O}_{2}$ produced little 8-oxo-dG but LOOH produced significant amounts of it under conditions with $0.5 \mu \mathrm{mol} / \mathrm{L} \mathrm{Fe}{ }^{2+}$, which is the physiological concentration of $\mathrm{Fe}^{2+} \cdot{ }^{(39,40)}$ Under conditions of physiologically excessive amounts of $\mathrm{Fe}^{2+}$, both $\mathrm{H}_{2} \mathrm{O}_{2}$ and LOOH produced considerable amounts of 8-oxo-dG. Then, lipid micelles enclosing $\mathrm{dG}$ were prepared by adding the oxidants to the micelles (Table 3). LOOH produced a large amount of 8-oxo-dG at a concentration one-tenth of that of $\mathrm{H}_{2} \mathrm{O}_{2}$, and thus was a more reactive oxidant on $\mathrm{dG}$ than $\mathrm{H}_{2} \mathrm{O}_{2}$ at a physiological concentration of $\mathrm{Fe}^{2+}$. These results clearly demonstrate that lipid peroxides like $\mathrm{LOOH}$ is preferential oxidant species for the formation of 8-oxo$\mathrm{dG}$. The preferential point for lipid peroxides as the endogenous oxidants is considered to be more easily mixed in lipid membrane than water-soluble $\mathrm{H}_{2} \mathrm{O}_{2}$ and to approach to the guanosine residue (Table 3 ). The formation mechanism of 8 -oxo-dG is suggested to be a direct addition of lipid peroxyl radicals on C8 position of guanosine as reported in our previous paper, ${ }^{(13)}$ though the details should be examined.

Next, the oxidant potency was compared in hepatic mitochondria among lipid peroxides, $\mathrm{LOOH}$ and $\mathrm{PCOOH}$, and $\mathrm{H}_{2} \mathrm{O}_{2}$ (Table 4). $\mathrm{PCOOH}$ produced large amounts of 8-oxo-dG, but the difference was not significant, indicating that the lipid peroxides were more reactive than $\mathrm{H}_{2} \mathrm{O}_{2}$. $\mathrm{PCOOH}$ generated in the mitochondrial membranes seems likely to attack the mitochondrial DNA more frequently than $\mathrm{H}_{2} \mathrm{O}_{2}$ because the mitochondrial membranes enclosing the DNA are composed of phospholipids such as PC and easily form the peroxides of unsaturated fatty acids in the second position of PC. . $^{(14,16,28)}$

As a living cell model to evaluate the oxidant potency, HepG2 cells were employed (Table 5). The addition of $\mathrm{H}_{2} \mathrm{O}_{2}$ and LOOH increased slightly 8 -oxo-dG levels in the cells. Living cells have been known to possess antioxidant enzymes such as GPx. Then, the cells were pretreated with enzyme inhibitor before adding the oxidants. $\mathrm{LOOH}$ produced significantly larger amounts of 8-oxo$\mathrm{dG}$ than $\mathrm{H}_{2} \mathrm{O}_{2}$, showing that the lipid peroxides oxidized DNA in the cells but not $\mathrm{H}_{2} \mathrm{O}_{2}$ under the conditions of decreasing antioxidant enzyme activity. Enzyme activity has been recognized to decrease or to exceed the capacity when living cells undergo oxidative stress in which reactive oxygen species are excessively generated. Such oxidative stress is induced under the following conditions: excessive activity of the mitochondrial electron transfer system after surplus intake and leakage of electrons to oxygen, ${ }^{(41)}$ full production of superoxide anions by cytochrome P450 monooxygenase for the detoxification of xenobiotics and/or alcohol, ${ }^{(42,43)}$ and neutrophils removing invading pathogens using reactive oxygen species such as perchloric acid formed by myeloperoxidase, ${ }^{(44,45)}$ among others. ${ }^{(46)}$ Under oxidative stress conditions, dG in DNA will be oxidized to 8-oxo-dG. Against this background, next, the bioavailable antioxidants that can suppress the formation of 8-oxo-dG were examined using HepG2 cells.

After HepG2 cells had been pre-incubated with the antioxidants, their nuclei were isolated and treated with $\mathrm{LOOH}$, and then the formed amounts of 8-oxo-dG were compared among the antioxidants. NAC is a water-soluble antioxidant, and trolox is a modified chemical that becomes water-soluble by removing the lipid-soluble side chain from $\alpha$-tocopherol (Fig. 2). 2,6Dipalmitoyl ascorbic acid is modified to be lipid-soluble by esterification with palmitic acid on water-soluble ascorbic acid (Fig. 2). Ascorbic acid, trolox, and NAC showed no or weak antioxidant potency on the 8-oxo-dG formation induced by $\mathrm{LOOH}$, and 2,6-dipalmitoyl ascorbic acid and $\alpha$-tocopherol exhibited stronger antioxidant potency (Fig. 3). Thus, lipid-soluble antioxidants suppressed the 8-oxo-dG formation induced by lipid peroxides more effectively than water-soluble ones.

Most flavonoids are not water-soluble, and especially flavones and flavonols are insoluble in water and partially soluble in lipids. ${ }^{(47)}$ In terms of the 8 -oxo-dG formation inducing by lipid peroxides, several flavones and flavonols are clear antioxidants (Fig. 4). Flavone possessing no $\mathrm{OH}$ groups (Fig. 5), baicalein with three $\mathrm{OH}$ groups, and myricetin with six $\mathrm{OH}$ groups did not show antioxidant activity, while flavonol having one OH group, apigenin with three, luteolin with four, morin with five, and quercetin with five exhibited significant antioxidant potency. Thus, the antioxidant activity of flavonoids did not depend on the number of $\mathrm{OH}$ groups. Luteolin and quercetin exhibited greater activity than the other flavonoids, and both flavonoids possess a catechol structure in the B-ring of the flavonoid skeleton (Fig. 5). Catechol flavonoids have been recognized to be strong antioxidants, ${ }^{(38)}$ and quercetin has been reported to be a bioavailable antioxidant, although the flavonoids when ingested undergo conjugation in the intestinal absorption process. ${ }^{(48)}$ The conjugation is a masking reaction with glucuronide or sulfate and occurs on one of the $\mathrm{OH}$ groups of the flavonoid skeleton. After undergoing the conjugation, flavonoids retaining the catechol structure can exhibit antioxidant potency, and there is a probability of $2 / 3$ of quercetin retaining the catechol structure. Moon et al. ${ }^{(49)}$ reported that $2 / 3$ of quercetin in plasma exhibited antioxidant activity after quercetin had been ingested and incorporated into the blood circulation.

Carotenoids have been considered to be quenchers of singlet oxygen and to be weak antioxidants against lipid peroxides. ${ }^{(50)}$ Astaxanthin, canthaxanthin, and zeaxanthin are oxygen-containing carotenoids, namely, xanthophylls, and are lipid-soluble and partially soluble in water. $\beta$-Carotene did not show antioxidant potency, but the xanthophylls exhibited such activity on the 8-oxo$\mathrm{dG}$ formation induced by the lipid peroxides (Fig. 6). The xanthophylls possess one or two $\mathrm{OH}$ groups on their $\beta$-ionone ring (Fig. 7), which seem to contribute to their antioxidant activity. ${ }^{(51)}$ Dietary $\beta$-carotene has been recognized to be incorporated into the blood circulation and then into the cells of the body. ${ }^{(52)}$ Dietary xanthophylls have a lower incorporation rate, but can partly circulate in the body. ${ }^{(53-55)}$ Xanthophylls are probably bioavailable antioxidants acting against 8 -oxo-dG production. Thus, several lipid-soluble flavonoids and xanthophylls were able to suppress the formation of 8-oxo-dG in the living cells, which was probably attributable to ease of mixing with and entering into the biomembranes. ${ }^{(47,56)}$

It is concluded that oxidative injury of DNA is induced more abundantly by lipid peroxides than by $\mathrm{H}_{2} \mathrm{O}_{2}$, so lipid-soluble antioxidants such as vitamin $\mathrm{E}, 2$,6-dipalmitoyl vitamin $\mathrm{C}$, quercetin, and several xanthophylls could be available to prevent the oxidative injury of DNA.

\section{Acknowledgments}

This work was supported in part by a Grant-in-Aid for research from the Ministry of Education, Culture, Sports, Science and Technology, Japan (23580167).

\section{Conflict of Interest}

No potential conflicts of interest were disclosed. 


\section{References}

1 Boiteux S, Radicella JP. Base excision repair of 8-hydroxyguanine protects DNA from endogenous oxidative stress. Biochimie 1999; 81: 59-67.

2 Cheng KC, Cahill DS, Kasai H, Nishimura S, Loeb LA. 8-Hydroxyguanine, an abundant form of oxidative DNA damage, causes G----T and A----C substitutions. J Biol Chem 1992; 267: 166-172.

3 Hsu GW, Ober M, Carell T, Beese LS. Error-prone replication of oxidatively damaged DNA by a high-fidelity DNA polymerase. Nature 2004; 431: $217-$ 221.

4 Okamoto K, Toyokuni S, Uchida K, et al. Formation of 8-hydroxy-2'-deoxyguanosine and 4-hydroxy-2-nonenal-modified proteins in human renal-cell carcinoma. Int J Cancer 1994; 58: 825-829.

5 Musarrat J, Arezina-Wilson J, Wani AA. Prognostic and aetiological relevance of 8-hydroxyguanosine in human breast carcinogenesis. Eur J Cancer 1996; 32A: 1209-1214.

6 Kasai H. Analysis of a form of oxidative DNA damage, 8-hydroxy-2'-deoxyguanosine, as a marker of cellular oxidative stress during carcinogenesis. $\mathrm{Mu}$ tat Res 1997; 387: 147-163.

7 Marnett LJ. Oxyradicals and DNA damage. Carcinogenesis 2000; 21: 361370.

8 Olinski R, Gackowski D, Rozalski R, Foksinski M, Bialkowski K. Oxidative DNA damage in cancer patients: a cause or a consequence of the disease development? Mutat Res 2003; 531: 177-190.

9 Malins DC, Holmes EH, Polissar NL, Gunselman SJ. The etiology of breast cancer. Characteristic alteration in hydroxyl radical-induced DNA base lesions during oncogenesis with potential for evaluating incidence risk. Cancer 1993; 71: 3036-3043.

10 Hussain SP, Harris CC. Molecular epidemiology of human cancer: contribution of mutation spectra studies of tumor suppressor genes. Cancer Res 1998; 58: 4023-4037.

11 Foksinski M, Kotzbach R, Szymanski W, Oinski R. The level of typical biomarker of oxidative stress 8-hydroxy-2'-deoxyguanosine is higher in uterine myomas than in control tissue and correlates with size of the tumor. Free Radic Biol Med 2000; 29: 597-601.

12 Djuric Z, Heilbrun LK, Lababidi S, Berzinkas E, Simon MS, Kosir MA. Levels of 5-hydroxymethyl-2'-deoxyuridine in DNA from blood of women scheduled for breast biopsy. Cancer Epidemiol Biomarkers Prev 2001; 10: 147-149.

13 Goto M, Ueda K, Hashimoto T, et al. A formation mechanism for 8-hydroxy2'-deoxyguanosine mediated by peroxidized 2'-deoxythymidine. Free Radic Biol Med 2008; 45: 1318-1325.

14 Henderson JR, Swalwell H, Boulton S, Manning P, McNeil CJ, Birch-Machin MA. Direct, real-time monitoring of superoxide generation in isolated mitochondria. Free Radic Res 2009; 43: 796-802.

15 Yeh GC, Henderson JP, Byun J, André d'Avignon D, Heinecke JW. 8-Nitroxanthine, a product of myeloperoxidase, peroxynitrite, and activated human neutrophils, enhances generation of superoxide by xanthine oxidase. Arch Biochem Biophys 2003; 418: 1-12.

16 Jezek P, Hlavatá L. Mitochondria in homeostasis of reactive oxygen species in cell, tissues, and organism. Int J Biochem Cell Biol 2005; 37: 2478-2503.

17 Devasagayam TP, Steenken S, Obendorf MS, Schultz WA, Sies H. Formation of 8-hydroxy(deoxy)guanosine and generation of strand breaks at guanine residues in DNA by singlet oxygen. Biochemistry 1999; 30: 6283 6289.

18 Terao J. Cholesterol hydroperoxides and their degradation mechanism. Subcell Biochem 2014; 77: 83-91.

19 Henle ES, Luo Y, Gassmann W, Linn S. Oxidative damage to DNA constituents by iron-mediated fenton reactions. The deoxyguanosine family. $J$ Biol Chem 1996; 271: 21177-21186.

20 Niles JC, Wishnok JS, Tannenbaum SR. Peroxynitrite-induced oxidation and nitration products of guanine and 8-oxoguanine: structures and mechanisms of product formation. Nitric Oxide 2006; 14: 109-121.

21 Shukla PK, Mishra PC. Catalytic involvement of $\mathrm{CO}_{2}$ in the mutagenesis caused by reactions of $\mathrm{ONOO}^{-}$with guanine. J Phys Chem B 2008; 112: 4779-4789.

22 Valavanidis A, Vlachogianni T, Fiotakis C. 8-Hydroxy-2'-deoxyguanosine (8-OHdG): a critical biomarker of oxidative stress and carcinogenesis. J Environ Sci Health C Environ Carcinog Ecotoxicol Rev 2009; 27: 120-139.

23 Niki E. Free radical initiators as source of water- or lipid-soluble peroxyl radicals. Methods Enzymol 1990; 186: 100-108.

24 Morier-Teissier E, Bernier JL, Lohez M, Catteau JP, Hénichart JP. Free radi- cal production and DNA cleavage by copper chelating peptide-anthraquinones. Anticancer Drug Des 1990; 5: 291-305.

25 Pryor WA. Oxy-radicals and related species: their formation, lifetimes, and reactions. Annu Rev Physiol 1986; 48: 657-667.

26 Park JW, Floyd RA. Lipid peroxidation products mediate the formation of 8hydroxydeoxyguanosine in DNA. Free Radic Biol Med 1992; 12: 245-250.

27 Esterbauer H, Schaur RJ, Zollner H. Chemistry and biochemistry of 4-hydroxynonenal, malonaldehyde and related aldehydes. Free Radic Biol Med 1991; 11: 81-128.

28 Hruszkewycz AM, Bergtold DS. The 8-hydroxyguanine content of isolated mitochondria increases with lipid peroxidation. Mutat Res 1990; 244: 123128.

29 Kanazawa K, Ashida H. Dietary hydroperoxides of linoleic acid decompose to aldehydes in stomach before being absorbed into the body. Biochim Biophys Acta 1998; 1393: 349-361.

30 Takagi T, Mitsuno Y, Masumura M. Determination of peroxide value by the colorimetric iodine method with protection of iodine as cadmium complex. Lipids 1977; 13: 147-151.

31 Little C, O'Brian PJ. The effectiveness of lipid peroxide in oxidizing protein and non-protein thiols. Biochem J 1968; 106: 419-423.

32 Wrona M, Korytowski W, Rózanowska M, Sarna T, Truscott TG. Cooperation of antioxidants in protection against photosensitized oxidation. Free Radic Biol Med 2003; 35: 1319-1329.

33 Kim SJ, Nara E, Kobayashi H, Terao J, Nagao A. Formation of cleavage products by autoxidation of lycopene. Lipids 2001; 36: 191-199.

34 Qu B, Li QT, Wong KP, Ong CN, Halliwell B. Mitochondrial damage by the "pro-oxidant" peroxisomal proliferator clofibrate. Free Radic Biol Med 1999; 27: $1095-1102$

35 Azuma Y, Hashimoto T, Nomura H, Das SK, Ozaki Y, Kanazawa K. Fucoxanthin induced apoptosis in human hepatocarcinoma $\mathrm{HepG}_{2}$ cells. $J$ Clin Biochem Nutr 2008; 43(Suppl 1): 273-276.

36 Steinbrenner H, Bilgic E, Alili L, Sies H, Brenneisen P. Selenoprotein P protects endothelial cells from oxidative damage by stimulation of glutathione peroxidase expression and activity. Free Radic Res 2006; 40: 936-943.

37 Paglia DE, Valentine WN. Studies on the quantitative and qualitative characterization of erythrocyte glutathione peroxidase. J Lab Clin Med 1967; 70: $158-169$.

38 Kanazawa K, Uehara M, Yanagitani H, Hashimoto T. Bioavailable flavonoids to suppress the formation of $8-\mathrm{OHdG}$ in HepG2 cells. Arch Biochem Biophys 2006; 455: 197-203.

39 Kakhlon O, Cabantchik ZI. The labile iron pool: characterization, measurement, and participation in cellular processes. Free Radic Biol Med 2002; 33: 1037-1046.

40 Gackowski D, Kruszewski M, Bartlomiejczyk T, Jawien A, Ciecierski M, Olinski R. The level of 8-oxo-7,8-dihydro-2'-deoxyguanosine is positively correlated with the size of the labile iron pool in human lymphocytes. $J$ Biol Inorg Chem 2002; 7: 548-550.

41 Sohal RS, Forster MJ. Caloroc restriction and the aging process: a critique Free Radic Biol Med 2014; 73: 366-382.

42 Werck-Reichhart D, Feyereisen R. Cytochromes P450: a success story. Genome Biol 2000; 1: REVIEWS3003.

43 Loquercio C, Federico A. Oxidative stress in viral and alcoholic hepatitis. Free Radic Biol Med 2003; 34: 1-10.

44 Postma NS, Mommers EC, Eling WN, Zuidema J. Oxidative stress in malaria; implications for prevention and therapy. Pharm World Sci 1996; 18: $121-$ 129.

45 Tao F, Gonzalez-Flecha B, Kobzik L. Reactive oxygen species in pulmonary inflammation by ambient particulates. Free Radic Biol Med 2003; 35: 327 340 .

46 Muralikrishna AR, Hatcher JF. Phospholipase A2, reactive oxugen species, and lipid peroxidation in cerebral ischemia. Free Radic Biol Med 2006; 40: 376-387.

47 Murota K, Matsuda N, Kashino Y, et al. $\alpha$-Oligoglucosylation of a sugar moiety enhances the bioavailability of quercetin glucosides in humans. Arch Biochem Biophys 2010; 501: 91-97.

48 Murota K, Terao J. Antioxidative flavonoid quercetin: implication of its intestinal absorption and metabolism. Arch Biochem Biophys 2003; 417: 12-17.

49 Moon JH, Tsushida T, Nakahara K, Terao J. Identification of quercetin 3-O$\beta$-D-glucuronide as an antioxidative metabolite in rat plasma after oral administration of quercetin. Free Radic Biol Med 2001; 30: 1274-1285. 
50 Ouchi A, Aizawa K, Iwasaki Y, et al. Kinetic study of the quenching reaction of singlet oxygen by carotenoids and food extracts in solution, development of a singlet oxygen absorption capacity (SOAC) assay method. J Agric Food Chem 2010; 58: 9967-9978.

51 Terao J. Antioxidant activity of $\beta$-carotene-related carotenoids in solution. Lipids 1989; 24: 659-661.

52 Cutler RG. Carotenoids and retinol: their possible importance in determining longevity of primate species. Proc Natl Acad Sci US A 1984; 81: 7627-7631.

53 Rüfer CE, Moeseneder J, Briviba K, Rechkemmer G, Bub A. Bioavailavility of astaxanthin stereoisomers from wild (Oncorhynchus spp.) and aquacultured (Salmo salar) salmon in healthy men: a randomized, double-blind study.
Br J Nutr 2008; 99: 1048-1054.

54 White WS, Stacewicz-Sapuntzakis M, Erdman JW Jr, Bowen PE. Pharmacokinetics of beta-catotene and canthaxanthin after ingestion of individual and combined doses by human subjects. J Am Coll Nutr 1994; 13: 665-671.

55 Hashimoto T, Ozaki Y, Mizuno M, et al. Pharmacokinetics of fucoxanthinol in human plasma after the oral administration of kombu extract. Br J Nutr 2012; 107: 1566-1569.

56 Sinha R, Joshi A, Joshi UJ, Srivastava S, Govil G. Localization and interaction of hydroxyflavones with lipid bilayer model membranes: a study using DSC and multinuclear NMR. Eur J Med Chem 2014; 80: 285-294. 